\title{
Portrait of Online Learning during the Covid-19 Pandemic (a Case Study on Solo Raya
}

\author{
Vocational Teacher)
}

\author{
Siswandari ${ }^{1}$, Sri Sumaryati², Susilaningsih ${ }^{3}$, Asri Diah Susanti ${ }^{4}$, Nurhasan Hamidi ${ }^{5}$, Binti Muchsini ${ }^{6}$, \\ Muhtar $^{7}$
}

\section{srisumaryati@staff.uns.ac.id²}

\begin{abstract}
This study aims to identify the implementation of online learning conducted by teachers to provide the best service to students during online learning activities Covid19 pandemic. This study involved 254 vocational school teachers in Solo Raya. Quantitative data is netted through questionnaires that are disseminated using Google Form facilities. Meanwhile, we obtained qualitative information from interviews designed using WhatsApp and telephone facilities. The results showed that $52.2 \%$ of teachers admitted to agreeing not to have any health complaints. Teachers are always fit for online learning, with $58.9 \%$ agreeing. Teachers were always excited when they were online, with $68.4 \%$ answering agreed. The implementation of online learning requires more service time. $64.9 \%$ of teachers provide services about 14 hours per day. $64.1 \%$ of teachers agreed that they are ready to provide online services to students outside the working hours. Teachers have RPP as a sign of online learning, with $68.8 \%$ of teachers agreeing.
\end{abstract}

Keywords: Online learning, vocational school teachers, Covid-19 pandemic

Abstrak: $\quad$ Penelitian ini bertujuan untuk mengidentifikasikan pelaksanaan pembelajaran online yang dilakukan oleh guru dalam rangka memberikan pelayanan terbaik kepada siswa pada masa pandemi Covid-19. Penelitian ini melibatkan 254 guru SMK di Solo Raya. Data kuantitatif dijaring melalui angket yang disebarkan dengan menggunakan fasilitas Google Form. Sementara itu data kualitatif diperoleh dari wawancara yang dirancang menggunakan fasilitas WhatsApp dan telepon. Hasil penelitian menunjukkan bahwa sebesar 52,2 \% guru mengaku setuju tidak mempunyai keluhan kesehatan apapun. Guru selalu bugar pada pelaksanaan pembelajaran online, sebesar $58,9 \%$ menjawab setuju. Guru selalu bersemangat pada saat megajar secara online, sebesar $68,4 \%$ menjawab setuju. Pelaksanaan pembelajaran online membutuhkan waktu pelayanan lebih banyak, sebesar $64,9 \%$ guru memberikan pelayanan sekitar 14 jam per hari. Sebesar $64,1 \%$ guru mengaku setuju bahwa siap memberikan layanan online kepada siswa diluar ketentuan jam kerja. Guru mempunyai RPP sebagai rambu-rambu pembelajaran online, sebesar $68,8 \%$ guru menjawab setuju.

Kata Kunci: Pembelajaran online, Guru SMK, pandemi Covid-19

Submitted: July $2021 \quad$ Reviewed: August $2021 \quad$ Accepted: August $2021 \quad$ Published: September 2021




\title{
INTRODUCTION
}

\begin{abstract}
T The Era of Corona Virus Disease Pandemic (Covid-19) significantly influences all aspects of human life, ranging from social, political, economic, and primarily educational elements. Related to the aspects of education, during the covid-19 pandemic encouraged various parties, especially policymakers, to make multiple logical efforts to keep teaching and learning running. When schools had to be closed due to the pandemic, UNICEF encouraged all countries, including Indonesia, in this case, the Ministry of Education, to immediately conduct mitigations that include changes in learning strategies. A good response related to the mitigation is the issuance of Government Regulation of the Republic of Indonesia Number 21 of 2020 concerning Large-Scale Social Restrictions (PSBB) to Accelerate the Handling of COVID-19. Article 4 of the Government Regulation contains large-scale social restrictions that include the disbursement of schools and workplaces. In addition to Indonesian Government Regulations No.21 of 2020, the Ministry of Education also issued Circular Letter No. 4 of 2020 concerning the Implementation of Education in the Emergency Period of Covid-19. This is what drives the change in learning implementation strategy during the pandemic.
\end{abstract}

The change in learning strategy during the Covid-19 pandemic provides opportunities and challenges for teachers. Opportunities to learn more about the implementation of learning strategies that must be different than usual. The various technologies that can be utilized and at the same time answer the demands of the pandemic era have not all been touched by teachers in the past, as well as good experiences that have never been obtained in the normal period before the pandemic. In addition, the pandemic also presents various challenges to teachers, especially related to the implementation of learning to provide the best service to students. In addition, there are still some other problems such as additional workload, anxiety about student learning achievements, pressures in completing the learning plan, and the effectiveness of learning (the Star, 2020; Darmalaksana, 2020; Treacy, Prendergast, O'Meara, 2019; Panigrahi, Srivastava, Sharma, 2018; Coopasami, Knight, Pete, 2017; Kuntarto, 2017; Bloom, 2016; Lamberton, Leana, Williams, 2013; Scheier \& Carver, 2013; Sankey, Birch, Gardiner, 2011).

These challenges will be reviewed and sought solutions through scientific approaches so that the results are beneficial to the government and educators. They will better understand what to supply to learners for the future. The future is synonymous with digitization. The industrial revolution 4.0 was marked by the development of the internet of things (loT), followed by new technologies in data science, artificial intelligence, robotics, cloud, three-dimensional printing, and nanotechnology (Hocheng, 2018; Salgues, 2018; Gufron, 2018). In the digital age, work varies greatly and differs from the current one (Bosma, 2018; World Economic Forum, 2018). This era plus the covid-19 pandemic requires the ability to work with various technologies, especially those that are computerized (Hussin, 2019; Salgues, 2018; Hayes et al., 2000; Mazzarol, Hosie \&Jacobs, 1998). But in reality, the digital literacy rate of about $60 \%$ of non-tech teachers is still relatively low (Ministry of Education, 2018; Gutmundsdottir \&Hatlevik, 2017). This is still added to the statement from various sources that learning in the era of the covid-19 pandemic indicates that it has not been effective.

Online learning has been a necessity in education since recent years (He, Xu, \&Kruck, 2014) because face-to-face (offline) learning is considered closed and assumed to be a traditional model and requires better learning facilities with the use of information technology (Panigrahi, Srivastava, \&Sharma, 2018). Education during Work From Home (WFH) and Study From Home (SFH) requires strengthening online or online learning (Darmalaksana, 2020). Experts point out that all resources should be deployed in order to support online education that will become mainstream by 2025 (Palvia et 
al., 2018). Abbas (2018) informs that internal factors that affect learning difficulties consist of health, interest in learning, attention, lazy learning, and learning habits. External factors consist of learning, parental control, demands of work, active organization, mischievous peers, and free association. While the efforts of educators in overcoming learning difficulties basically vary according to their respective characters. In addition, Sari (2017) has identified four internal factors that cause the biggest causes of learning difficulties, namely, learning habits, learning motivation, learning ability, and understanding interest factors. While external factors consist of educators, parents, friends get along, and the environment. In line with previous research, Aryani (2017) showed internal factors that cause learning difficulties, as follows: interest $77.28 \%$, health $13.63 \%$, attitude towards learning by $9.09 \%$. External factors that cause learning problems are families $50.00 \%$ schools $44.74 \%$, and society $5.26 \%$.

These challenges will be studied and sought solutions through scientific approaches so that the results are not only beneficial for the government but also for educators. They will better understand what to be supplied to the learner for the future. The future is synonymous with digitalization. The industrial revolution 4.0 is characterized by the development of the internet of things (IoT) followed by new technologies in data science, artificial intelligence, robotics, cloud, three-dimensional printing and nanotechnology (Hocheng, 2018; Salgues, 2018). In the digital era the field of work is very varied and different from the current one (Bosma, 2018; World Economic Forum, 2018). This era plus the covid-19 pandemic requires the ability to work with various technologies, especially those that are computerized (Hussin, 2019; Salgues, 2018). But in reality the digital literacy rate of about $60 \%$ of non-tech teachers is still relatively low (Kemendikbud, 2018; Gutmundsdottir \& Hatlevik, 2017). This is still coupled with statements from various sources that learning in the era of the covid-19 pandemic indicates it has not been effective.

The purpose of this study is to identify the implementation of online learning conducted by teachers in order to provide the best service to students in terms of health, fitness, spirit, duration of services related to learning, applications used, signal conditions, teacher readiness in providing services outside the provisions of working hours, available learning facilities and several other things related to online learning during the Covid-Covid-Covid pandemic. 19. In addition, it is also hoped that this research will be a reference to improve the quality and quality assurance of the implementation of education and learning in an integrated manner, for example, related to improving the ability to choose teacher's digital learning and literacy strategies.

\section{RESEARCH METHODS}

The method that researchers can use in order to carry out their research is referred to as the research method (Merriam, 2009; Babbie, 1975; Cohen, Manion, Morrison, 2007; Dominowski, 1980; Gay, 2005). This study uses mixed methods with an embedded approach (Cameron, 2009; Creswell \&Clark, 2007). Through these mixed methods, researchers focused on measurement problems and understated the meaning and context of behaviors and processes that occur in patterns related to various observable factors. The participant in this research is 254 Vocational school teachers in Surakarta Province. Random sampling is a sampling technique in this study. Random sampling technique can be done if the population members are homogeneous so that each member of the population has the same opportunity to represent the population. The data needed in this study is the condition of teachers in carrying out online learning seen from 1) teacher health during the practice of online learning, 2) the fitness and spirit of teachers when teaching online, 3) the frequency of providing services in school hours and outside school hours, 4) Learning strategies used by teachers during the covid 19 pandemic, and 5) obstacles faced by teachers during learning in the pandemic covid 19. The 
data collection techniques used are 1) Questionnaires designed and disseminated through Google Forms to facilitate the networking of data from teachers in the Solo Raya area; 2) In-dept-interviews to certain informants to test the integrity of information obtained through questionnaires, and 3) Study documentation to complete the data source.

\section{RESULTS AND DISCUSSION}

The situation of the covid-19 pandemic brings changes to the educational aspects that require education to be conducted online. Online learning is learning that is done with the help of electronic devices as its main component. The implementation of online learning has a challenge for teachers to provide the best service to their performance.

Some studies have concluded that online learning during the COVID-19 pandemic has an impact not only on students and parents but also impacts teachers. Some studies have concluded that; online learning during the COVID-19 pandemic has an impact not only on students and parents, but also impacts teachers (Code et al., 2020; Wargadinata, 2020). Teachers with their duties as teachers, educators, and mentors must have good health to carry out their duties well. Teacher readiness in preparing their students through learning activities determines success in education maintenance. Thus teachers are positioned to improve the quality of educational outcomes, which are influenced by the ability of teaching professionals and the level of teacher welfare. Therefore, when the teacher's health condition is not good, the learning will not run effectively and unsatisfactory (Purwanto et al., 2020). So, teachers need to pay attention to their health conditions in the implementation of learning. Based on the questionnaire obtained results that can be seen in the following figure.

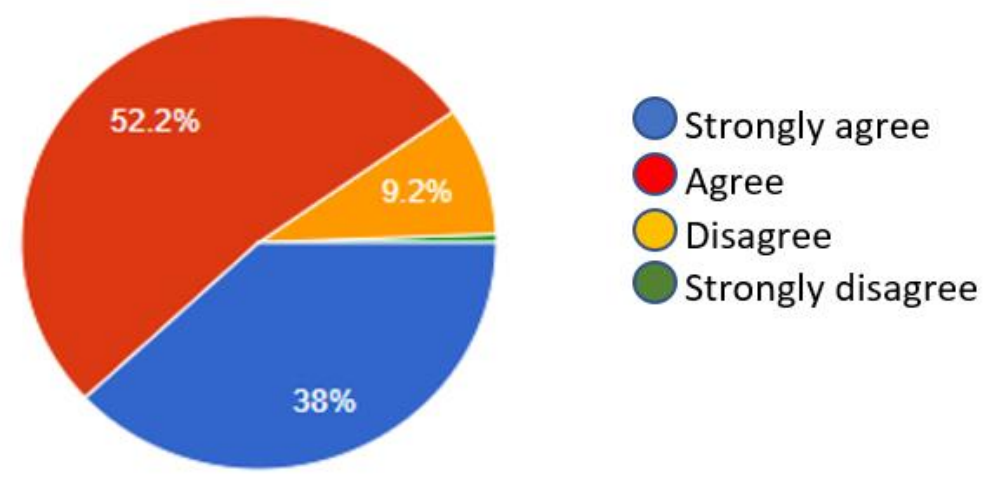

Figure 1. Teachers Health Complaints

Referencing Figure 1,52.5\% of teachers had no health complaints in carrying out online learning. Teachers as professionals have main tasks, including planning, carrying out learning, and assessing learning outcomes. To be able to carry out the study, one of the good efforts is that the teacher must be in a fit state. Although the implementation of learning is done online, the physical fitness condition of a teacher remains a thing to note. When the teacher's fitness condition is disturbed, the implementation of online learning will be disrupted. Based on the questionnaire obtained, results can be seen in the following diagram. 


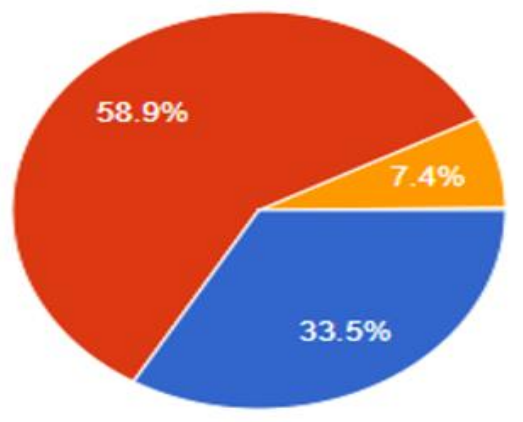

Strongly agree

Agree

Disagree

Strongly disagree

Figure 2. Teachers Always Fit

Pandemic conditions do not discourage teachers from providing the best service in the implementation of online learning. Online learning is an effective way to improve the quality of learning in vocational schools because it has variations in enhancing students' motivation, satisfaction, and interaction(Belaya, 2018). Online learning during the pandemic has a challenge, one of which is to maintain students' motivation. The role of a teacher is to keep students motivated to stay good (Hakim \& Mulyapradana, 2020). Teachers have an essential role in fostering students' learning motivation through learning activities based on the teacher's experience and abilities. When teachers are passionate about the implementation of learning, students will be motivated in following the learning. Based on the questionnaire obtained results that can be seen from the following diagram:

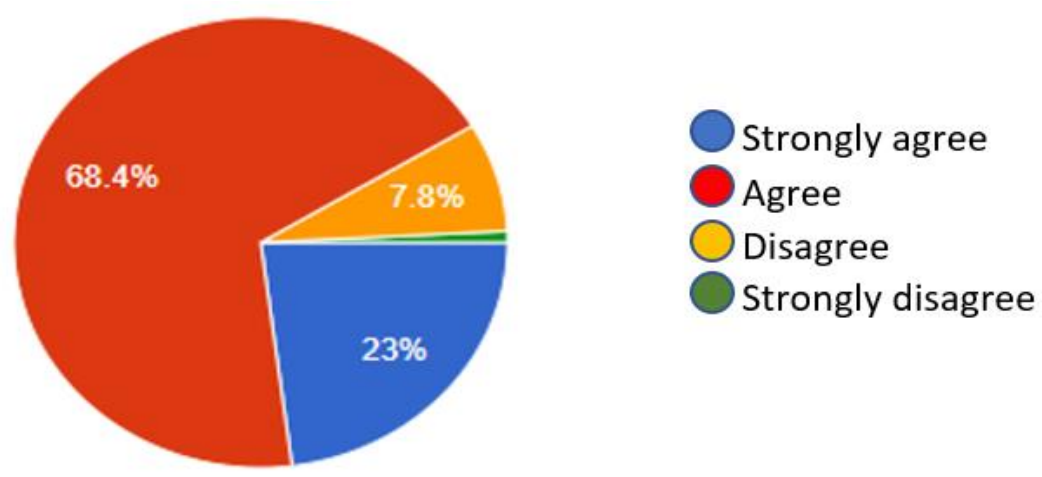

Figure 3. Teachers Are Always Excited when Teaching Online

Based on the diagram obtained, $68.4 \%$ of teachers are always excited when teaching online. Although teachers are excited about the actual conditions of the implementation of online learning, $90 \%$ of students can only focus on learning online for about 45 minutes. These obstacles can occur due to poor signal conditions for some areas of the suburbs, resulting in impaired concentration of students and unable to focus on online learning. Obtained information about $20 \%$ of students does not have laptops or mobile phones to support online learning implementation. Another obstacle is the lack of online learning facilities, especially for teachers who teach practice and sports.

The implementation of online learning has easy because the teacher can do the performance anytime and anywhere without time restrictions (Sobron et al., 2019). Based on the statement, the actual condition of the implementation of online learning takes longer for a teacher to provide the best service for students. Based on the results of the questionnaire obtained results can be seen from the following diagram: 


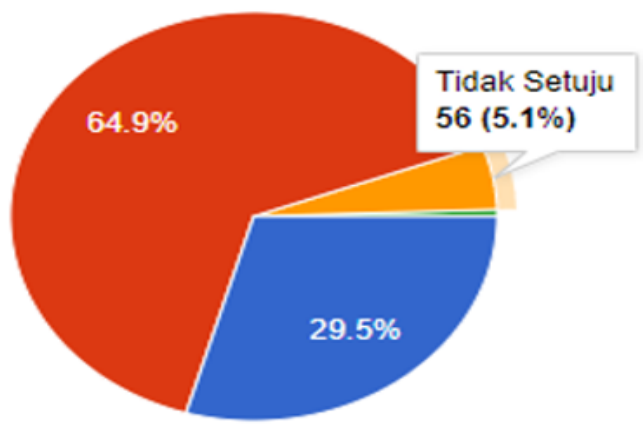

Strongly agree

Agree

Disagree

Strongly disagree

Figure 4. Teachers provide services about 14 hours per day

From the diagram above, $64.9 \%$ of teachers agreed that teachers provide 14 hours per day. In actual conditions, teachers not only provide services during teaching hours but more than that. Student's ability to understand learning materials varies because each student has a different point of view and understanding of the same material. When students learn independently, sometimes students do not understand the material taught by the teacher. It is not uncommon when students who do not know or understand the materials led by students will ask the teacher. In such conditions, teachers must provide services to students even if it is outside the provisions of working hours. When asked by teachers whether teachers are ready to offer online services to students outside the working hours' requirements, $27.2 \%$ of teachers answered firmly, $64.1 \%$ of teachers answered they agreed, and $8.2 \%$ of teachers answered disagreed. This indicates that teachers are willing to provide online services outside the terms of working hours. Can be seen in more detail in the following diagram:

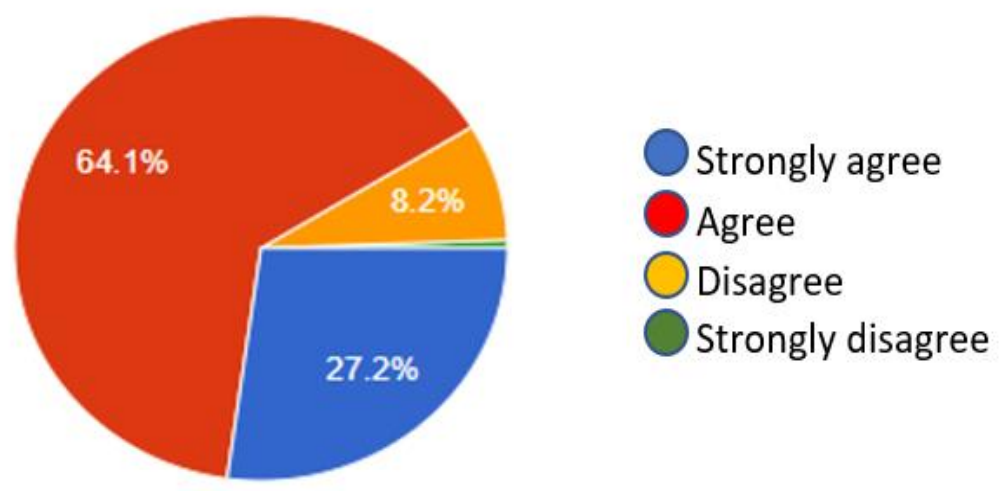

Figure 5. Teachers Ready to Provide Online Services to Students outside the Working Hours Provisions

The picture above indicates that the teacher wants to provide online services outside the provisions of working hours. Working hours become unlimited because they have to communicate and coordinate with students, parents, teachers, and other teachers. Not every teacher is not easy to learn technology, so working hours are not limited; even on weekdays, teachers are still required to prepare for the implementation of learning.

Online learning is not just about moving material through the internet, and it is not just about sending tasks and questions through social media applications. Online learning should be planned, implemented, and evaluated, just like implementing learning in the classroom(Syarifudin, 2020). Ideal online learning planning includes preparing lesson materials, the use of media, approaches, methods, and assessments that will be implemented to achieve the specified objectives. Although learning is 
conducted online, teachers must still prepare a Learning Implementation Plan that contains learning strategies that can be used as signs in implementing online learning. Based on the results of the questionnaire obtained results can be seen from the following diagram:

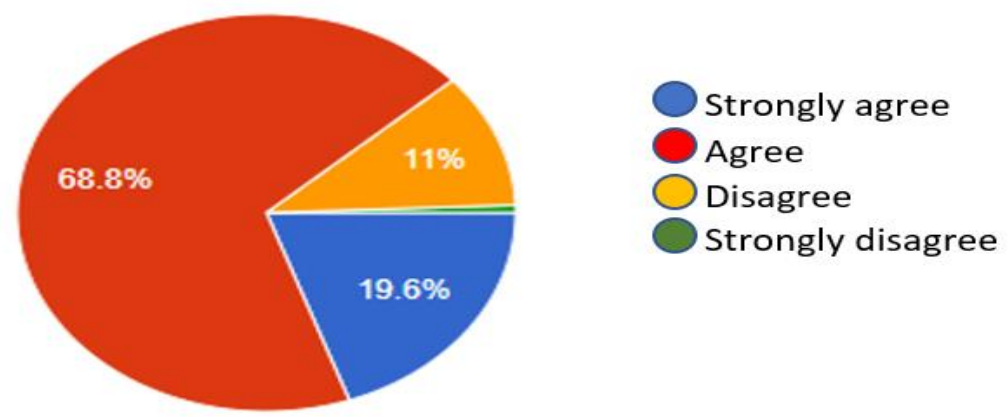

Figure 6. Teachers have RPP that contains Online Learning Strategies

From the diagram above, it appears that $68.8 \%$ of teachers chose the agreed answer; this shows that in the implementation of online learning, teachers still have RPP as a sign of learning implementation. With the RPP, it will make it easier for teachers to prepare and carry out knowledge. However, more than $50 \%$ of teachers are less able to develop exciting learning strategies or approaches. So that in the implementation of online learning, teachers do not utilize applications that can facilitate students to interact with teachers. Such interactions can be done by using applications such as zoom or google meet. Only $20 \%$ of teachers can use applications such as zoom or google meet in the implementation of online learning. The rest use WhatsApp applications to support the implementation of online learning. Based on the information obtained, more than $80 \%$ of teachers do not know students' economic conditions; therefore, most teachers utilize WhatsApp during the online learning process for the sake of continuity of learning.

\section{CONCLUSIONS AND RECOMMENDATIONS}

The above research results revealed that in the implementation of online learning, teachers provide the best service to students. $52.2 \%$ of teachers agreed not to have any health complaints. Teachers were always fit for online learning, with $58.9 \%$ agreeing. Teachers were always excited when they were online, with $68.4 \%$ answering agreed. The implementation of online learning requires more service time; $64.9 \%$ of teachers provide services about 14 hours per day. $64.1 \%$ of teachers agreed that they are ready to provide online services to students outside the working hours. Teachers have RPP as a sign of online learning, with $68.8 \%$ of teachers agreeing. In the actual condition in the implementation of online learning, $90 \%$ of students are only able to focus on online learning for about 45 minutes. More than $50 \%$ of teachers are less able to develop varied and exciting learning strategies or approaches. As many as $20 \%$ of teachers can use the zoom app and google meet; the rest use the WhatsApp app. More than $80 \%$ of teachers are unaware of the economic condition of students. Therefore the implementation of the learning process utilizes WhatsApp. $20 \%$ of students do not have a laptop or mobile phone for online learning. Other obstacles in online learning performance are poor signal conditions for some areas and a lack of online learning facilities for practical and sports subjects. This research is expected to be continued to explore the implementation of online learning during the pandemic so that other factors need to be considered regarding online learning. 


\section{REFERENCES}

Babbie, E.R. (1975). The Practice Of Social Research. California: Wadsworth Publishing.

Belaya, V. (2018). The Use of e-Learning in Vocational Education and Training ( VET ): Systematization of Existing Theoretical Approaches. Journal of Education and Learning, 7(5), 92-101. https://doi.org/10.5539/jel.v7n5p92

Bloom, P. (2016). Against Empathy - The Case for Rational Compassion. London: The Boldey Head

Bosma, N., \& Kelley, D. (2019). Global Entrepreneurship Monitor-2018/2019: Global Report

Cameron, R., (2009). A sequential mixed model research design: design, analytical and display issues. International Journal of Multiple Research Approaches , 3 (2), 140-152.

Code, J., Ralph, R., \& Forde, K. (2020). Pandemic designs for the future: perspectives of technology education teachers during COVID-19. Information and Learning Science, 121(5-6), 409-421. https://doi.org/10.1108/LS-04-2020-0112

Cohen, L., Manion, L., Morrison, K. (2007). Research Methods in Education. 6th Ed. London: Routledge

Coopasami, M., Knight, S., \& Pete, M. (2017). e-Learning readiness among nursing students at the Durban University of Technology. Health Sagesondheid, pp. 300-306.

Darmalaksana, W. (2020). WhatsApp Kuliah Mobile. Bandung: Fakultas Ushuluddin UIN Sunan Gunung Djati.

Dominowski. 1980. Research Methods, Englewood Cliffs: Prentice-Hall Inc.

Evans, C. (2008). The effectiveness of m-learning in the form of podcast revision lectures in higher education, Computers \& Education, 50 (2).

Gay, L.R. 2005. Research Methods. New York: Prentice Hall Inc.

Hakim, M., \& Mulyapradana, A. (2020). Pengaruh Penggunaan Media Daring dan Motivasi Belajar Terhadap Kepuasan Mahasiswa Pada Saat Pandemi Covid-19. 4(2), 154-160

Hayes D et.al. (2000). Integrating Computer-Based Learning in Schools: Findings from Research in Six NSW Government Schools. Paper presented at the Australian Association of Research in Education (AARE) Annual Conference, University of Sydney, 4 - 7 December 2000.

He, W., Xu, G., \& Kruck, S. (2014). Online Education for the 21st Century. Journal of Information Systems Education.

Hocheng, H. (2018) . Crossing-border Journey of e-learning in higher education. A keynote

Hussin, A.A. (2019). Education 4.0 Made Simple: Ideas For Teaching. International Journal of Education \& Literacy Studies, 6 (3), 92-98.

Jamaluddin, Dindin and Ratnasih, Teti and Gunawan, Heri and Paujiah, Epa (2020). Pembelajaran daring masa pandemik Covid-19 pada calon guru: hambatan, solusi dan proyeksi. Jurnal Sains Matematika dan Statistika, 7 (1), 65-74.

Jarboe, P.K. (2005). The Changing Contexs of Higher Education and Four Possible Futures for Distance Education. University of Minnesota. 
Kuntarto, E. (2017). Keefektifan Model Pembelajaran Daring Dalam Perkuliahan Bahasa Indonesia Diperguruan Tinggi. Journal Indonesian Language Education and Literature ( ILEAE), 3 (1).

Lamberton, C.M, Leana, C.R., and Williams, J.M. (2013). Measuring Empathetic Care: Development and Validation of a Self-Report Scale. Journal of Applied Gerontology, 34 (8), 1028-1053.

Mangundayao, A.B., Briones, S.J. \& Mefragata, J.D. (2003). Sustaining Technician Education in the Age of Globalization. Research Report: Technological University of the Philippines.

Mathias, D. (2019): Researching Educational Apps: Ecologies, Technologies, Subjectivities and Learning Regimes. Journal Learning, Media and Technology, 44 (4). DOI:S10.1080/17439884.2019.1667824.

Merriam, S.B. (2009). Case Study Research in Education: A Qualitative Approoach. San Francisco: Jossey-Bass Publishers.

Palvia, S., Aeron, P., Gupta, P., Mahapatra, D., Parida, R., Rosner, R., \& Sindhi, S. (2018). Online Education: Worldwide Status, Challenges, Trends, and Implications. Journal of Global Information Technology Management.

Panigrahi, R., Srivastava, P. R., \& Sharma, D. (2018). Online learning: Adoption, continuance, and learning outcome-A review of the literature. International Journal of Information Management, $43,1-14$.

Purwanto, A., Akbari, M., Fahlev, M., Mufid, Eva Agistiawati, A., Cahyono, Y., \& Suryani, P. (2020). Impact of Work From Home (WFH) on Indonesian Teachers Performance During the Covid-19 Pandemic: An Exploratory Study. International Journal of Advanced Science and Technology. 29 (5), $6235-6244$.

Salgues, B. (2018). Society 5.0 - Industry of the future, technologies, methods, and tools. Volume 1. London: John Wiley \& Sons Inc.

Sankey, M., Birch, D., \& Gardiner, M. (2011). The impact of multiple representations of content using multimedia on learning outcomes across learning styles and modal preferences. International Journal of Education and Development using ICT, 7 (3), 18-35.

Scheier, M. F., \& Carver, C. S. (2013). Self-Consciousness Scale speech in eLFA 2018 (e-Learning Forum Asia 2018 "e-learning for the future", National Taipei University Of Bussines, Taipei, Taiwan.

Sobron, A. N., Bayu, Rani, \& Meidawati, S. (2019). Persepsi Siswa dalam Studi Pengaruh Daring Learning Terhadap Minat Belajar IPA. Jurnal Pendidikan Dan Multikulturalisme, 1(2), 30-38.

Syarifudin, A. S. (2020). Implementasi Pembelajaran Daring untuk Meningkatkan Mutu Pendidikan Sebagai Dampak Diterapkannya Social Distancing. Metalingua Jurnal Pendidikan Bahasa Dan Sastra Indonesia, 31-34.

The Star. 2020. Transitioning to the new normal in education, https://www.thestar.com.my/opinion/letters/2020/04/28/transitioning-to-the-new-normal-ineducation. diakses tgl. 31 Mei 2020.

Treacy, P., Prendergast, M., O'Meara. (2019). A "new normal": Teachers' experiencees of the day-today impact of incentivising the study of advanced mathematics. Journal in Mathematics Education. DOI:10.1080/14794802.2019.1668832 
Wargadinata, W., Maimunah, I., Dewi, E., \& Rofiq, Z. (2020). Student's Responses on Learning in the Early COVID-19 Pandemic. Tadris: Jurnal Keguruan Dan IImu Tarbiyah, 5(1), 141-153. https://doi.org/10.24042/tadris.v5i1.6153

World Economic Forum. (2018). The Future of Jobs Report 2018. In Weforum.org. https://doi.org/10.1177/0891242417690604 